\title{
Effect of Kolb's Learning Styles under Inductive Guided-Inquiry Learning on Learning Outcomes
}

\author{
Ida Bagus Nyoman Sudria \\ Dr., Universitas Pendidikan Ganesha, Indonesia, ibnsudria@gmail.com
}

I Wayan Redhana

Prof., Universitas Pendidikan Ganesha, Indonesia, redhana.undiksha@gmail.com

\section{Made Kirna}

Dr., Universitas Pendidikan Ganesha, Indonesia, mdkirna@gmail.com

\section{Diah Aini}

Universitas Pendidikan Ganesha, Indonesia, ainiidiahh@gmail.com

\begin{abstract}
This study aimed to examine the effect of Kolb's learning styles on chemical learning activities and achievement of reaction rate taught by inductive guidedinquiry learning. The population was eleventh grade Science students of a senior secondary school having relatively good academic input based on national testing results in Bali, Indonesia. Samples involved the entire students of five classes taken by cluster sampling from the whole nine classes of the population. Data were collected by Kolb's learning style inventory for the learning styles, observation and document recording for learning performances, post-test for the cognitive achievement, and questionnaires for student's perceptions. Data analyses were conducted qualitatively in assigning the learning styles, and describing learning performances and perceptions, and used ANOVA followed by Scheffé's post hoc test for the effect of learning styles on the cognitive achievement. The results showed: (1) the student learning styles were 35.8\% Convergers, $30.0 \%$ Assimilators, $17.5 \%$ Divergers, and $16.7 \%$ Accommodators; (2) learning styles significantly affected the achievement with only superiority of the Convergers over the accommodators; and (3) the inductive guided-inquiry learning of chemical topic which involves concrete evidences via laboratory work was fruitful for all learners of all learning styles.
\end{abstract}

Keywords: Kolb's learning styles, inductive reasoning, guided-inquiry, scientific performances, cognitive achievement

Citation: Sudria, I. B. N., Redhana, I W., Kirna, I M., \& Aini, D. (2018). Effect of Kolb's Learning Styles under Inductive Guided-Inquiry Learning on Learning Outcomes. International Journal of Instruction, 11(1), 89-102. https://doi.org/10.12973/iji.2018.1117a 


\section{INTRODUCTION}

Student learning achievement depends on various factors, but the effect of learning styles is on question (Cuevas, 2015; Ulstad, Halvari, Sørebø, \& Deci, 2016; Tatar, Tüysüz, Tosun, \& İlhan). Learning style constitutes preferred ways of learning in terms of absorbing, managing, and processing information which is obtained either by remembering, reasoning, and/or problem solving. Kolb's model of learning styles was developed on the basis of Kolb's experiential learning cycle phases (Kolb, Boyatzis, \& Mainemelis, 2000) involving concrete experience (CE), reflective observation (RO), abstract conceptualization (AC), and active experimentation (AE) which aligned with the phases of scientific learning. Kolb Learning styles consist of four learning styles: Divergers, Assimilators, Convergers, and Accommodators. Learners are most successfully learning through concrete experiences and reflective observation for the Divergers, through reflective observation and abstract conceptualization for the Assimilators, through abstract conceptualization and active experiments for the Convergers, and through concrete experiences and active experimentation for the Accommodators.

Effective learning of science is recommended through investigative learning (Bruner in Shen, 2007). Moreover a variety of innovative learning models such as the models of inquiry learning, problem-based learning, and project-based learning which consider characteristics of the material and thinking patterns are recommended in developing a learning strategy (Akpan \& Beard, 2016; Ulstad et al., 2016). However, no one learning strategy is well-matched to all learning situations. Efforts to synchronize the student's learning style, learning model, and the material characteristics should be done to achieve optimal learning outcomes. Learning through inquiry will be successful if the learners have inquiry skill, but students of secondary schools commonly have not accurately had inquiry skills yet, and/or prefer guided inquiry learning (Bunterm et al., 2014; Sadeh \& Zion, 2012). In such conditions the use of guided inquiry model needs to be precisely investigated.

Sudria \& Sya'ban (2015) conducted concept analysis using Herron's format (Herron, 1977) and found that chemical topic of reaction rate for secondary school mostly deals with basic concepts belonging to concepts with no problems or concrete concepts, concepts based on the principles, and concepts with abstract attributes but have concrete examples. Furthermore, Sudria \& Sya'ban (2015) succeeded to develop prototype of inductive guided-inquiry learning tools on the reaction rate topic considering the characteristics of the identified concepts.

Assessment of scientific learning considers learning activities and situations, and achievement. The quality of learning would evolve in learning activities and formative assessment or post-test scores which attribute to scientific learning targets such as scientific conceptions (Redhana, et al., 2017). This study examined the influence of Kolb's learning styles on learning activities and learning achievement of students through guided-inquiry learning model with inductive reasoning. 


\section{REVIEW OF LITERATURE}

Learning strategy should facilitate learners with different learning styles. A learning style refers to the preferred ways to learn such absorbing, processing, and managing information either by remembering, reasoning, and/or problem solving. Kozhevnikov (in Rogowsky, Calhoun, \& Tallal, 2015) reviewed that cognitive learning styles represent heuristics and based on which individuals can be grouped with respect to regulatory function they apply to multiple levels of information processing from perceptual to metacognitive. Learning style is a combination of how learners absorb and then organize information.

Although the theoretic supports on validity and reliability of Kolb's learning style inventory (LSI) were criticized, the Kolb's learning style model is widely accepted. Kolb's learning style model consists of four operationally defined learning styles that are Diverger, Assimilator, Converger, and Accommodator. Kolb learning styles were developed on the basis of the Kolb experiential learning cycle which is illustrated in a Cartesian diagram (Kolb, Boyatzis, \& Mainemelis, 2000). The vertical axis presents the phases of the knowledge acquisition as a continuum from concrete experience (CE) at the bottom to abstract conceptualization (AC) at the top, while the horizontal axis presents the phases of the knowledge transformation as a continuum from reflective observation (RO) at the right hand to active experimentation (AE) at the left. The Kolb learning cycles enable students to build the knowledge, skills, values, and attitudes (Kolb \& Kolb, 2005).

The nature of Kolb's learning style indicates the preferences of learning activities characterized by two consecutive phases of the Kolb's learning cycle or resembles a quadrant. The Diverger, Assimilator, Converger, and Accommodator assign the quadrant between $\mathrm{CO}$ and $\mathrm{RO}$ phases, $\mathrm{RO}$ and $\mathrm{AC}$ phases, $\mathrm{AC}$ and $\mathrm{AE}$ phases, and $\mathrm{AE}$ and $\mathrm{CE}$ phases respectively. The nature of Kolb's learning styles are described in many references (Kolb, Boyatzis, \& Mainemelis, 2000; Kolb \& Kolb, 2005; Koob \& Funk, 2002; Ilnicki-stone, 2012). Divergers prefer to learn through living alone in a concrete world and then transform their experiences through reflective observation. Assimilators prefer to learn through the analysis of concrete phenomena of reflective observation and then make an association or assimilation to create understanding. Convergers prefer to learn from abstract conceptual knowledge and then transform what they have learned into active experiment. Accommodators prefer a combination of concrete experience or feeling and active experiments or doing. They tend to gain knowledge through living alone in a concrete world and transform their experiences into active experiment.

The scientifically aligning phases of the Kolb's experiential learning cycle and its concern on cognitive maturity (Hudak \& Anderson in Koob \& Funk, 2002) makes it appropriate for science learning. There are six specific propositions supporting Kolb's learning styles namely: learning (1) is best conceived as a process, (2) is a continuous process grounded in experience, (3) requires the resolution of conflicts between dialectically opposed modes of adaptation to the world, (4) is a holistic process of adaptation, (5) involves transaction between the person and environment, and (6) is the process of creating knowledge (Kolb in Koob \& Funk, 2002). 
Some factors may affect the learning styles such as the level of cognitive development of students or grade, habits of thinking patterns that have been formed, conception types which are constructed, and frequent use of a learning model, and other contextual factors such as life experiences and socio-environment of the school (Kolb \& Kolb, 2005). Student academic capacity input might be related to the maturity level of cognitive development on the students. A shift in the learning style would be influenced by the success of students undergoing the cognitive development phases (Piaget, 1953). Visual and kinesthetic learning styles were rather dominant than auditory learning style at elementary school.

The basic patterns of inductive and deductive reasoning could also be considered in assessing the Kolb's experiential learning cycle and Kolb's learning styles. Inductive reasoning starts with concrete examples, while deductive reasoning starts with a concept or abstraction (Thomond, 2004). The entire Kolb's experiential learning cycle mainly involves two consecutive reasoning episodes (Sudria, 2016). First, building generalization deals with inductive reasoning through concrete experience, reflective observation and abstract conceptualization phases. Second, verifying the generalization/knowledge which has been constructed involves deductive reasoning through abstract conceptualization and active experimentation phases. Although both reasoning patters apply contrast thinking patterns, they are complementary if inductive reasoning is consistently applied during the entire knowledge generating episode and deductive reason is consistently applied during the entire verification episode of the generalizations. Otherwise, inconsistency of both reasoning patterns in each episode for commencing learners of scientific learning will promote root learning (Sudria, 2016).

Chemistry is a science that studies material and its changes via three levels of understanding of macroscopic, sub-microscopic, and symbolic levels (Gabel, 1999; Johnstone, 1991; Sevian \& Talanquer, 2014). From the sub-microscopic chemical aspects, such atomic or molecular structure and distribution reveal macroscopic phenomena of a matter and its represented symbol. The connection among the three levels challenges a learner to think and investigate (Gabel, 1999), and requires right exercises since the beginning of meaningful learning in chemistry, otherwise it would be a problem for commencing students (Sudria, 2006). Reaction rate is a topic for secondary school Chemistry which should deal with the three levels of understanding.

No learning model matches to all learning situations. Inquiry learning model is recommended for learning through invention. Guided inquiry is one of the various inquiry learning models which mainly consists of five steps, namely observation, manipulation, generalization, verification and application (Vishnumolakala, Southam, Treagust, Mocerino, \& Qureshi, 2017; Fay, Grove, Towns, \& Bretz, 2007; MartinHansen, 2002). Guided inquiry provides guidance in formulating investigative questions and/or other phases if required commonly for learners whose inquiry skill has not committed or established (Banchi, H., Bell, 2008; Wenning \& Khan, 2011; Shen, 2007; Kuhlthau, 2010; Dounas-Frazer \& Reinholz, 2015; Vishnumolakala et al., 2017). Learning performances such as observing of investigation pursuing phenomena, formulating investigative questions, and designing investigative experiments are 
important roles of inquiry or scientific skills. Implementation of guided inquiry will train students to develop skills of scientific learning, then optimize the conduction of the Kolb's experiential learning cycle as the basis of Kolb's learning styles.

\section{METHOD}

This comparative study was conducted at a secondary public school of SMAN 1 Singaraja in Bali, Indonesia. The school consistently has good academic student input based on national testing results. Samples involved the entire students of five science classes taken by cluster sampling from the whole nine science classes of the population. This study required several learning data under implementation of inductive guidedinquiry learning model. This study involved recording learning activities under inductive guided-inquiry learning, identification of the students' learning styles according to Kolb's model, and then comparing students' post-test scores among the identified learning styles of the students. The learning styles and post-test scores of the students were recorded at the end of the whole four learning units, while learning activities were recorded along the learning processes under the implementation of inductive guidedinquiry learning.

Lessons are normally conducted in each class under the implementation of inductive guided-inquiry learning, and the learning style of the groups were assigned at the end of the whole implemented lessons of four units. Groups with different learning styles would be in same classes. Learning content is limited to the topic of the chemical reaction rate which included four learning units $(\mathrm{P} 1, \mathrm{P} 2, \mathrm{P} 3, \& \mathrm{P} 4)$. The learning units mainly involved defining of reaction rate based on a computer-based animated experiment for P1, laboratory work on factors affecting reaction rates for P2, collision theory using experiment data recorded at $\mathrm{P} 2$ for learning unit 3, and reaction rate applications on society through discussion for P4. Each learning unit used inductive guided-inquiry model developed by Sudria (2015). The model followed five steps of a learning cycle that were observing of investigation pursuing phenomena, questioning, collecting data, associating and communicating. Each learning unit was equipped with learning tools which consisted of lesson plans, worksheets, learning text of the topic, and assessment of learning.

Learning performances of observing, questioning, and designing experiments were recorded through worksheet documents. In addition, laboratory work performances were also observed using scoring rubric guidance at learning units of P1 and P2. Laboratory skills were limited to observing and using laboratory equipment and chemicals. Assessment of cognitive achievement was recorded via a post-test at the end of P4 for the whole content of the reaction rate topic using a cognitive test. Student perceptions regarding the overall aspects of learning were also collected at the end of lesson P4 through a questionnaire applying four perception categories that are strongly agree (SA), agree (A), disagree (D), and strongly disagree (SD).

The learning styles of the students were collected using Kolb's learning style inventory (LSI) adapted by Ilnicki-stone (2012) for Chemistry Class. The adapted Kolb's LSI on Chemical learning had the reliability coefficient of $0.74(\mathrm{n}=322)$ at the beginning of 
2012 and $0.84(n=337)$ at the end of 2012 (Ilnicki-stone, 2012). The translation in Indonesian version of the Kolb's LSI was used in our research. The students put their priority order of preferences into the four scales of which score 4 for the most preferred to score 1 for the least preferred. The preference scores of CE, RO, AC, and AE of each student were assigned to his/her learning style. The learning style of a student was determined by plotting his/her AE-RO and AC-CE scores in the Cartesian diagram of the experiential learning cycle. The students assigned in the quadrant between $\mathrm{CE}$ and OR were Divergers, between OR and AC were Assimilators, between AC and AE were Convergers, and between AC and CE were Accommodators (Kolb \& Kolb, 2005). The percentages of the students belonging to every learning style, then to the whole distribution showed the learning style profile of students of the samples or the population.

The post-test scores were collected using a cognitive test developed by Sudria (2015). The test consisted of 20 multiple choice items with reliability coefficient of 0.65 and 5 essay items with reliability coefficient of 0.68 . The overall scores weighed $60 \%$ for the total multiple choice items and $40 \%$ for the total essay items. The effect of the learning styles on cognitive achievement was analyzed using one-way ANOVA followed by Scheffé's post hoc test if the significant effect is found. The post-test scores of student's cognitive achievement was the dependent variable, while the Kolb's learning style model which consists of the four learning styles was the independent variable under inductive guided-inquiry learning condition. After that, the data of students in each learning style category were completed with their learning activities scores that had been recorded along with the learning process in order to describe learning activities as the support of the gained cognitive achievement of the students for each learning style type.

\section{FINDINGS}

All students of five sample classes completed and returned the Kolb's LSI, and showed that the distribution of students were 21 or $17.5 \%$ Divergers, 36 or 30,0\% Assimilators, 43 or $35.8 \%$ Convergers, and 20 or $16,7 \%$ Accommodators. The four learning styles resembled a normal distribution.

Almost all of students of the samples fully followed the inductive guided-inquiry learning and all of them undertook the post-test. A summary of one-way ANOVA results of the effect of the learning styles on the cognitive learning achievement is presented in Table 1.

Table 1

The summary of the one-way ANOVA results

\begin{tabular}{lccccc}
\hline \multicolumn{1}{c}{ Result } & Sum of Squares & df & mean Square & F & Sig. \\
\hline Between Groups & 1633.042 & 3 & 544.347 & 5.017 & 0,003 \\
\hline Within Groups & 12587.255 & 116 & 108.511 & & \\
\hline Total & 14220 & 119 & & & \\
\hline
\end{tabular}

The ANOVA results indicated that learning styles influenced cognitive achievement with significance of 0.003 . As the significance of the effect was lower than the accepted 
significance of 0,05 , then Scheffé's post hoc test gave results as shown in Table 2. The Scheffé's post hoc test results showed that only the post-test scores of students with converger learning style were significantly better than the post-test scores of the students with accommodator learning style.

Table 2

Summary of theScheffé's post hoc test results

\begin{tabular}{lllll}
\hline Learning Styles (I) & Learning Styles (J) Mean Difference (IJ) & Std. Error & Sig. \\
\hline \multirow{3}{*}{ Assimilator } & Converger & -0.90841 & 2.35323 & 0.985 \\
\cline { 2 - 5 } & Diverger & 6.60405 & 2.86031 & 0.155 \\
\cline { 2 - 5 } Converger & Accommodator & 7.84133 & 2.90512 & 0.069 \\
\hline \multirow{3}{*}{ Diverger } & Assimilator & 0.90841 & 2.35323 & 0.985 \\
\cline { 2 - 5 } & Diverger & 7.51246 & 2.77321 & 0,067 \\
\cline { 2 - 5 } & Accommodator & $8.74974^{*}$ & 2.81941 & 0,026 \\
\hline \multirow{3}{*}{ Accommodator } & Assimilator & -6.60405 & 2.86031 & 0.155 \\
\cline { 2 - 5 } & Converger & -7.51246 & 2.77321 & 0,067 \\
\cline { 2 - 5 } & Accommodator & 1.23729 & 3.25465 & 0.986 \\
\hline & Assimilator & -7.84133 & 2.90512 & 0.069 \\
\cline { 2 - 5 } & Converger & $-8.74974^{*}$ & 2.81941 & 0,026 \\
\cline { 2 - 5 } & Diverger & -1.23729 & 3.25465 & 0.986 \\
\hline
\end{tabular}

Learning activity data of scientific performances of (a) observing of investigative generating phenomena, (b) formulating investigative questions, and (c) designing investigative experiments were recorded during the four consecutive learning units of P1 to P4. The activity scores were assigned to the student activities recorded in the applied worksheets P1 to P4 as presented in Figure 1.

The figure shows that observing investigative generating phenomena consistently improved from poor to good performances for the all of learning styles along the four learning units. In addition, the students of Convergers and Assimilators slightly improved along the whole learning processes both for questioning and designing experiments, but for the Divergers and Accommodators only improved at P2 and then remained at poor performances at P3 and P4 for both questioning and designing experiments. All learning styles showed performance improvement at P2 which applied concrete work of laboratory experiment of factors affecting reaction rate.

The learning process only involved laboratory work performances or psychomotor skills in P1 and P2 units as only P1 and P2 applied laboratory works, while P3 and P4 were conducted through discussions. Although P1 used computerized animation of measuring gaseous reaction product along with time of the chemical reaction took place. Laboratory performance recordings were limited to observing, using laboratory equipment and chemicals, and communicating skills. The average performance scores of the laboratory are presented in Table 3. Overall the average psychomotor skills were very good with an average score of 4.26 out of the maximum score of 5.00. The 
Convergers and Assimilators gained slightly better performances than Divergers and Accommodators.

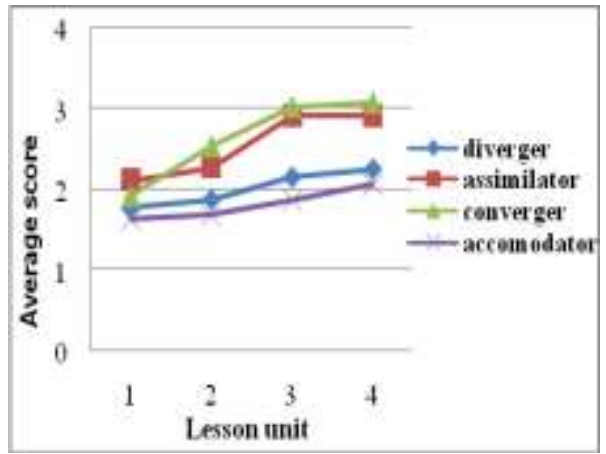

(a) Observing performance of students

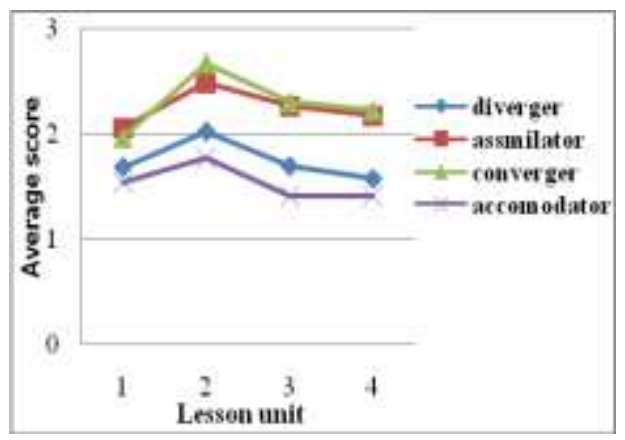

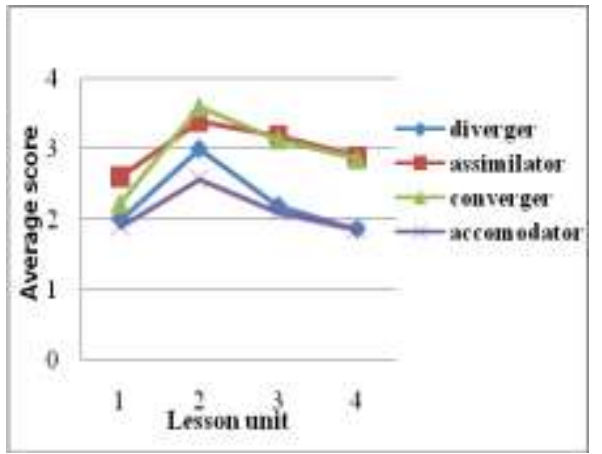

(b) Questioning performance of students

(c) Experiment designing performance of students

Figure 1

The developing scores of student's observing, questioning, and designing experiment along the four consecutive learning units P1 to P4.

Table 3

Conversion laboratory student performance scores

\begin{tabular}{|c|c|c|c|c|}
\hline No. & Learning styles & Numbers of Students & Average score & Category \\
\hline 1 & Diverger & 21 & 4.09 & Very good \\
\hline 2 & Assimilator & 36 & 4.23 & Very good \\
\hline 3 & Conveger & 43 & 4.25 & Very good \\
\hline 4 & Accommodator & 20 & 4.07 & Very good \\
\hline \multicolumn{2}{|c|}{ Overall performances } & 120 & 4.16 & Very good \\
\hline
\end{tabular}

The percentages of students whose perceptions on the whole worksheets, process skills, understanding of concepts, and experiences of the inductive guided-inquiry learning were collected at the end of $\mathrm{P} 4$ are presented in Table 4 . The perception category ranged 
from strongly agree (SA), agree (A), disagree (D), and strongly disagree (SD). Above $80 \%$ of the students of every learning style gave agreement $(\mathrm{SA}+\mathrm{A})$. The Divergers and Convergers gave slightly higher agreement toward the learning aspects of inductive guided-inquiry learning with percentages of $91.7 \%$ and $88.1 \%$ respectively.

Table 4

Percentage distribution of student's perception categories toward several aspects of inductive guided-inquiry learning

\begin{tabular}{|c|c|c|c|c|c|c|}
\hline \multirow{2}{*}{\multicolumn{2}{|c|}{$\begin{array}{l}\text { Aspects and } \\
\text { perception categories }\end{array}$}} & \multicolumn{4}{|c|}{ Learning styles } & \multirow{2}{*}{-Average } \\
\hline & & Divergers & Assimilators & Convergers & Accommodators & \\
\hline \multirow{4}{*}{ Worksheets } & $\% \mathrm{SA}$ & 21.83 & 9.83 & 19.89 & 25.56 & 19.28 \\
\hline & $\% \mathrm{~A}$ & 64,32 & 72.44 & 67.18 & 57.99 & 65.48 \\
\hline & $\% \mathrm{D}$ & 18.25 & 15.35 & 11.65 & 13.67 & 14.73 \\
\hline & $\% \mathrm{SD}$ & 0 & 2.37 & 1.28 & 3.79 & 1.86 \\
\hline \multirow{4}{*}{ Process skills } & $\% \mathrm{SA}$ & 32.18 & 14.51 & 23.59 & 25.16 & 23.86 \\
\hline & $\% \mathrm{~A}$ & 60.94 & 70.05 & 67.4 & 64.05 & 65.61 \\
\hline & $\% \mathrm{D}$ & 6.88 & 14.02 & 8.75 & 10.31 & 9.99 \\
\hline & $\% \mathrm{SD}$ & 0 & 0.7 & 0.26 & 0.49 & 0.36 \\
\hline \multirow{4}{*}{$\begin{array}{l}\text { Conceptual } \\
\text { learning }\end{array}$} & $\% \mathrm{SA}$ & 29.86 & 14.05 & 24.18 & 17.99 & 21.52 \\
\hline & $\% \mathrm{~A}$ & 66.37 & 73.26 & 62.51 & 65.4 & 66.89 \\
\hline & $\% \mathrm{D}$ & 3.77 & 10.81 & 13.31 & 16.62 & 11,13 \\
\hline & $\% \mathrm{SD}$ & 0 & 2.36 & 0 & 0 & 0.59 \\
\hline \multirow{4}{*}{$\begin{array}{l}\text { Experience } \\
\text { for students }\end{array}$} & $\% \mathrm{SA}$ & 25.56 & 17.89 & 23.96 & 24.63 & 23.01 \\
\hline & $\% \mathrm{~A}$ & 65.54 & 64.33 & 63.83 & 55.21 & 62.23 \\
\hline & $\% \mathrm{D}$ & 8.57 & 16.38 & 10.65 & 19.95 & 13.89 \\
\hline & $\% \mathrm{SD}$ & 0.24 & 1.95 & 1.56 & 0.2 & 0.99 \\
\hline \multirow{4}{*}{ Average } & $\% \mathrm{SA}$ & 27.38 & 14.07 & 22.9 & 23.09 & 21.86 \\
\hline & $\% \mathrm{~A}$ & 64.29 & 70.02 & 65.23 & 60.66 & 65.05 \\
\hline & $\% \mathrm{D}$ & 9.37 & 14.14 & 11.09 & 15.14 & 12.44 \\
\hline & $\% \mathrm{SD}$ & 0.06 & 1.85 & 0.77 & 1.12 & 0.95 \\
\hline \multicolumn{2}{|c|}{ Average\% $(\mathbf{S A}+\mathbf{A})$} & 91.67 & 84.09 & 88.13 & 83.75 & 86.51 \\
\hline
\end{tabular}

\section{DISCUSSION}

This study identified the numbers of the students of SMAN 1 Singaraja of the eleventh grade Science students who belonged to Convergers, Assimilators, Divergers, and Accommodators which were $35.8 \%, 30.0 \%, 17.5 \%$, and $16.7 \%$ respectively. Convergers and Assimilators were dominant. It showed that the students of SMAN 1 Singaraja mostly prefer to learn through thinking and theoretical and applicative learning. The results were consistent with the learning styles identified by Swari (2015) that the same secondary school and SMAN4 Singaraja which had relatively better academic input in Singaraja were dominantly of Convergers, but with no concern with learning model applied. Moreover, Swari (2015) found that other secondary schools in Singaraja (SMAN 2, SMAN 3, and the private schools) were different in which the Divergers and 
Assimilators were dominant, the same as what was found at secondary schools in Kerinci (Latisma, 2015). Other different findings showed that while the majority of Divergers and Accomodators were at the secondary school of SMA Bae Kudus (Marningsih, 2012), the majority of Assimilators at Dental Students (Hosseini, Amery, Emadzadeh, \& Babazadeh, 2015), and the majority of Convergers in Chemistry Courses were at first and second grade at Brock University, Ontario (Ilnicki-stone, 2012) with significant majority of abstract conceptualization (AC) over concrete experience (CE) and no significant difference was among active experience (AE) and reflective observation (RO). The dominance of different learning styles among secondary schools of SMAN 1 and SMAN 4 from the other secondary schools in Singaraja was likely to be influenced by the academic input of students. In fact, the SMAN 1 and SMAN 4 Singaraja had better academic input than the other senior high schools in the Singaraja city. It showed that high academic abilities tend to have a converger learning style. Input academic ability which represented cognitive development affects the distribution of learning styles in each school (Susilo, 2006).

This more controlled study found that learning styles affected the cognitive learning achievement, that is only Corvergers gained significantly higher average scores on cognitive than Accommodators. This finding was consistent with Kolb's comment that Convergers are able to use the ability of abstraction and apply theory well (Kolb in Kolb $\&$ Kolb, 2005). It might be due to the fact that Convergers already have a high level maturity in cognitive development with respect to Piaget's theory of cognitive development (Koob \& Funk, 2002). Ilnicki-stone (2012) found significantly positive correlation between AC-CE and final course grade for both Introductory Chemistry and General Chemistry courses. This is associated with the nature of chemical learning abilities that are abstract and the ability to understand the usefulness of the practice of chemistry concepts in everyday life.

This study also revealed that it was difficult to make the existence of Assimilators' dominance over Convergers via rather concrete situation of inductive guided-inquiry learning in well academic input of secondary schools. Even though Kolb\& Kolb (2005) and Koob (2002) mentioned that Convergers prefer inductive reasoning, due to the naturally cognitive maturity of Convergers. The increase of assimilator population that could be promoted by the implementation of well inductive learning would be followed by promotion of the Assimilators to the Convergers as cognitive maturity promotion which decreases the assimilator population. This study showed both Assimilators and Convergers steadily improved in observing, questioning, and designing skills of inductive or tentative experiments, although Convergers prefer deductive reasoning (Koob, 2002). The improvement was just only from poor to good category in observing and questioning skills, but they were still poor in designing skill which implied the perquisite inquiry skills that they had not mastered yet. Beside the possibility of promoting learning styles, inductive guided-inquiry learning is fruitful to improve the scientific skills. However, Divergers and Accommodators require more intensive guidance, especially in formulating investigative questions and designing experiments. Skills of using laboratory equipment and chemicals easily improve for all learning styles in inductive guided-inquiry learning. 
The fruitfulness of the inductive guided-inquiry learning is implied from high appreciations, $83.8 \%$ to $91.4 \%$ of the students strongly agree and agree, and consent to the use of it. Frequent and long term use of the model tends to continuously improve scientific skills and conceptual understanding. There was a wide range of changes in individual students, especially in active experimentation mainly on transforming experience rather than grasping experience in a teacher preparation program (Smith \& Rayfield, 2017)..

\section{CONCLUSION AND SUGGESTIONS}

Under the implementation of inductive guided-inquiry learning model, the Kolb's learning styles of the eleventh grade Science students of the secondary school with a good academic input influenced the students' scientific learning activities and achievement. Unlike the Divergers and Accommodators, the Convergers and Assimilators showed steady performance improvement on observing, questioning, and designing experiment. While the Divergers and Accommodators showed improving performances of observing, questioning, and designing experiments dealing with the only on concrete works or laboratory proving activities. Kolb's learning styles under the implementation of inductive guided-inquiry learning model influenced the cognitive learning achievement, but only Convergers gained higher post-test scores than Accommodators.

Worthwhile finding, all students with all learning styles showed very good performances in using laboratory equipment and chemicals under inductive guided-inquiry learning. This finding implies that the inductive guided-inquiry learning of chemical topic which involves concrete evidences via laboratory work was fruitful for all learners of all learning styles. This learning situation should be taken as a priority in learning of Chemistry.

The authors would like to thank Prof. H. Ali Saukah, M.A., Ph.D., Drs. Akhsanul In'am, M.N., Ph.D, and Dr. Istadi, S.T., M.T. for their useful comments on the draft resulting this submitted article, and to the IJI's reviewers who have reviewed this article for their useful comments.

\section{REFERENCES}

Akpan, J. P., \& Beard, L. A. (2016). Using constructivist teaching strategies to enhance academic outcomes of students with special needs. Universal Journal of Educational Research, 4(2), 392-398.

Banchi, H., \& Bell, R. (2008). Many levels of inquiry. Science and Children, (October), 26-29.

Bunterm, T., Lee, K., Ng Lan Kong, J., Srikoon, S., Vangpoomyai, P., Rattanavongsa, J., \& Rachahoon, G. (2014). Do different levels of inquiry lead to different learning outcomes? A comparison between guided and structured inquiry. International Journal of Science Education, 36(12), 1937-1959.

Cuevas, J. (2015). Is learning styles-based instruction effective? A comprehensive 
analysis of recent research on learning styles. Theory and Research in Education, 13(3), 308-333.

Dounas-Frazer, D. R., \& Reinholz, D. L. (2015). Attending to lifelong learning skills through guided reflection in a physics class. American Journal of Physics, 83(10), 881891.

Fay, M. E., Grove, N. P., Towns, M. H., \& Bretz, S. L. (2007). A rubric to characterize inquiry in the undergraduate chemistry laboratory. Chem. Educ. Res. Pract., 8(2), 212219.

Gabel, D. (1999). "Improving Teaching and learning through chemistry education research: A Look to the Feature". Journal of Chemical Education. 76, 548-553.

Herron, (1977). Problems associated with concept analysis, Science Education, 6(2), 185-199.

Hosseini, S. M., Amery, H., Emadzadeh, A., \& Babazadeh, S. (2015). Dental students'educational achievement in relation to their learning styles: A cross-sectional study in Iran.Global Journal of Health Science, 7(5), 152-158.

Ilnicki-stone, E. (2012). How learning styles, chemistry attitudes and experiences, confidence, and demographics correlate with academic success in first and second year chemistry courses. Thesis submitted in partial fulfillment of the requirements for the degree of Masters. Rertived $10 \quad$ Mei, 2016 from http://dr.library.brocku.ca/bitstream/handle/10464/4256/Brock_Ilnicki-

Stone_Elizabeth_2012.pdf?

In'am, Akhsanul, \& Hajar, S. (2017). Learning Geometry through discovery learning using a scientific approach akhsanul. International Journal of Instruction, 10(1), 55-70.

Johnstone, A. H. (1991). Why is science difficult to Learn ?Things are seldom what they seem. Journal of Computer Assisted Learning, 7(June), 75-83.

Kolb, D. A, Boyatzis, R. E., \& Mainemelis, C. (2000). Experiential learning theory: Previous research and new directions. Perspectives on Thinking Learning and Cognitive Styles, 1(216), 227-247.

Kolb, A. Y., \& Kolb, D. a. (2005). Learning styles and learning spaces : Enhancing experiential learning in higher education. Academy of Management Learning \& Education, 4(2), 193-212.

Koob, J. J., \& Funk, J. (2002). Kolb’s learning style inventory: Issues of reliability and validity. Research on Social Work Practice, 12(2), 293-308.

Kuhlthau, C. C. (2010). Guided inquiry: School libraries in the 21 st century. School Libraries Worldwide, 16(1), 17-28.

Latisma, Dj., Rahmi L.F., \& Indang, D. (2015). Trends analysis concept training student learning styles judging from the material in high school Kerinci Colloidal Systems. Proceedings of SEMIRATA, 523-532. 
Marningsih, T. (2012). Kolb learning styles relationship with student achievement. thesis. Retrived 3 March, 2017 from http://repository.uksw.edu/bitstream.

Martin-Hansen, L. (2002). Defining inquiry. The Science Teacher, 69, 34-37.

Piaget, J. (1953). The origins of intelligence in children. Journal of Consulting Psychology, 17(6), 467-467.

Redhana, I. W., Sudria, I. B. N., Hidayat, I., \& Merta, L. M. (2017). Identification of Chemistry Learning Problems Viewed from Conceptual Change Model. Jurnal Pendidikan IPA Indonesia, 6(2), 356-364.

Rogowsky, B. A., Calhoun, B. M., \& Tallal, P. (2015). Matching learning style to instructional method: Effects on comprehension. Journal of Educational Psychology, 107(1), 64-78.

Sadeh, I., \& Zion, M. (2012). Which type of inquiry project do high school biology students prefer: Open or guided? Research in Science Education, 42(5), 831-848.

Sevian, H., \& Talanquer, V. (2014). Rethinking chemistry: a learning progression on chemical thinking. Chem. Educ. Res. Pract., 15(1), 10-23.

Shen, M. M. (2007). Guided discovery teaching in primary schools to improve learning outcomes evaluated from independence students. Thesis. Retrived 27 February, 2017 from https://core.ac.uk/download/pdf/12347311.pdf

Smith, K. L., \& Rayfield, J. (2017). Student teaching changed me : A Look at Kolb 's learning style inventory scores before and after the student teaching experience, Journal of Agricultural Education, 58(1), 102-117.

Sudria, I. B. N. (2006). Pengembangan materi pembelajaran kimia di smp dalam rangka pendidikan science for all. Proseding Seminar Nasional Pendidikan IPA ke-3. Bandung: Universitas Pendidikan Indonesia.

Sudria, I. B. N. (2016). Pengembangan perangkat pembelajaran saintifik dengan penalaran dasar induktif dan deduktif. In A. Premono, I. W. Sugita, R. Sukarno, \& M. A. Akbar (Eds.).Proseding Konaspi VIII, 731-740. Jakarta: Universitas Negeri Jakarta.

Sudria I. B. N., \& Sya'ban, S. (2015). Pengembangan perangkat pembelajaran dengan pola berpikir induktif dan deduktif untuk pembinaan keterampilan saintifik siswa sekolah menengah. Research Report. Singaraja: LPPM Universitas Pendidikan Ganesha.

Susilo, M. J. (2006). Learning styles make smart. Yogyakarta: PINE

Swari, P. P 2015. Learning style analysis of high school students in Buleleng on Chemical education in terms of module Kolb learning styles. Thesis (Unpublished). Singaraja: Universitas Pendidikan Ganesha.

Tatar, E., Tüysüz, C., Tosun, C., \& İlhan, N. (2016). Investigation of factors affecting students' science achievement according to student science teachers. International Journal of Instruction, 9(2), 153-166. 
Thomond, P. N. (2004). Exploring and describing management action for the pursuit of disruptive innovation. PhDThesis. CranfieldUniversity.Retrieved 10 March, 2015 from https://dspace.lib.cranfield.ac.uk/...ThomondThesis.pdf.

Ulstad, S. O., Halvari, H., Sørebø, Ø., \& Deci, E. L. (2016). Motivation, learning strategies, and performance in physical education at secondary School. Advances in Physical Education, 6(1), 27-41.

Vishnumolakala, V. R., Southam, D. C., Treagust, D. F., Mocerino, M., \& Qureshi, S. (2017). Students' attitudes, self-efficacy and experiences in a modified process-oriented guided inquiry learning undergraduate chemistry classroom. Chem. Educ. Res. Pract., 18(2), 340-352.

Wenning, C. J., \& Khan, M. A. (2011). Levels of inquiry model of science teaching: learning sequences to lesson plans. Journal of Physics Teacher Education Online, 6(2), $17-20$. 